\title{
New Platinum(II) Complexes of Cycloalkanespiro-5-(2-thiohydantoins). Synthesis and Quantum Chemical Investigation
}

\author{
Petja Marinova, ${ }^{1, *}$ Marin Marinov, ${ }^{2}$ Vassil Delchev ${ }^{1}$ and Neyko Stoyanov ${ }^{3}$ \\ ${ }^{1}$ University of Plovdiv, Faculty of Chemistry, 4000 Plovdiv, 24 Tzar Assen St, Bulgaria \\ ${ }^{2}$ Agricultural University - Plovdiv, Faculty of Plant Protection and Agroecology, 4000 Plovdiv, 12 Mendeleev Blvd, Bulgaria \\ ${ }^{3}$ University of Ruse - Razgrad Branch, Department of Chemistry and Chemical Technology, 7200 Razgrad, \\ 47 Aprilsko Vastanie Blvd, Bulgaria \\ *Corresponding author: E-mail: marinova @ uni-plovdiv.bg
}

Received: 12-11-2014

\begin{abstract}
Synthesis and characterization of new Pt(II) complexes of cyclohexanespiro-5-(2-thiohydantoin) (L1) and cycloheptanespiro-5-(2-thiohydantoin) (L2) are discussed. The new complexes are studied by elemental analysis, IR and ${ }^{1} \mathrm{H} N M R$ spectroscopy. The free ligands are investigated by UV-Vis, IR, ${ }^{1} \mathrm{H}$ NMR, ${ }^{13} \mathrm{C}$ NMR and Raman spectroscopy. The ground-state equilibrium geometries of the ligands L1 and L2 and their complexes with $\mathrm{Pt}(\mathrm{II})$ are optimized at the BLYP/CEP-31G theoretical level.
\end{abstract}

Keywords: Cyclohexanespiro-5-(2-thiohydantoin); cycloheptanespiro-5-(2-thiohydantoin); DFT calculations; metal complexes

\section{Introduction}

Platinum-based drugs, and in particular cis-diamminedichloroplatinum(II) (best known as cisplatin), are employed for the treatment of a wide array of solid malignancies, including testicular, ovarian, cervical, head and neck, colorectal, bladder and lung cancers. Cisplatin is one of the most important metallodrug in the clinic practice, and though there are some derivatives like carboplatin, oxaliplatin and picoplatin in use in the clinic, the pace of further improvements has been slowed for many years. ${ }^{1}$ Despite its great curative success in testicular cancer, cisplatin is not universally effective in other cancer types and induces a number of toxic side effects. ${ }^{2-4}$ In addition, certain cancer types are resistant to cisplatin therapy. This resistance is either intrinsic or developed during prolonged treatment. ${ }^{5,6} \mathrm{New}$ platinum complexes have been pursued and investigated for their antitumor properties in order to circumvent these problems. Although well over a thousand complexes have been prepared and tested so far, ${ }^{7}$ only two other platinum drugs are approved for clinical use worldwide, and three additional compounds are approved for regional use in individual nations in Asia. ${ }^{8}$ These complexes (nedaplatin, lobaplatin and heptaplatin) operate with a mechanism of action similar to that of cisplatin, which involves DNA binding and transcription inhibition. Several platinum(IV) complexes have undergone clinical trials, but to date none have been approved for use in the United States. Examples include iproplatin, tetraplatin and satraplatin. Recently, J. Wilson et al. presented the synthetic methods for the preparation of platinum anticancer complexes.. Quiroga discussed the potential and limitations of the non-classical metallodrugs with platinum as metal. ${ }^{10}$ Despite the fact that cisplatin is one of the most effective and commonly used agents, nephro-, neuro- and ototoxicities are the main side effects of this drug. ${ }^{11} \mathrm{Re}-$ cently, N. Stojanović et al. investigated the cytotoxic activity of $\mathrm{Pt}(\mathrm{II})$ complexes with diazenecarboxamide against human cervical carcinoma HeLa cells. ${ }^{12} \mathrm{M}$. Saeidifar et al. synthesized a new watersoluble Pd(II) anionic complex and studied its cytotoxicity against human leukemia cells. $^{13}$ 
In the field of non-platinum compounds exhibiting anticancer properties, ruthenium complexes are very promising, showing activity on tumors which developed resistance to cisplatin or in which cisplatin is inactive. The first ruthenium compound NAMI-A (imidazolium transimidazoledimethylsulfoxidetetrachloro-ruthenate) entered phase I clinical trials in 1999 as an antimetastatic drug ${ }^{14,15}$ whereas the ruthenium complex KP1019 (transtetrachlorobis(indazole)ruthenate(III)) entered phase I clinical trials in 2003 as an anticancer drug which is among others very active against colon carcinomas and their metastases. ${ }^{16}$ Complexes such as RM175 (ONCO4417 [ $\left(\eta_{6}-\right.$ $\left.\left.\left.\mathrm{C}_{6} \mathrm{H}_{5} \mathrm{C}_{6} \mathrm{H}_{5}\right) \mathrm{RuCl}\left(\mathrm{H}_{2} \mathrm{NCH}_{2} \mathrm{CH}_{2} \mathrm{NH}_{2}-\mathrm{N}, \mathrm{N}^{\prime}\right)\right]^{+} \mathrm{PF}_{6}^{-}\right)$, prepared by P. J. Sadler, break the rule of the "activation by reduction mechanism", since they are based on the ruthenium at +2 oxidation state then having no need to be reduced to be active. ${ }^{17}$ RAPTA-T $\left(\mathrm{Ru}\left(\eta^{6}-\mathrm{C}_{6} \mathrm{H}_{5} \mathrm{Me}\right)(\mathrm{PTA}) \mathrm{Cl}_{2}\right)$, RDC11([ruthenium(phenanthroline)( $\mathrm{K}-\mathrm{C}, \mathrm{N}-(2$-phenylpyridine) $\left(\mathrm{NCMe}_{2}\right] \mathrm{PF}_{6}$ ) and $\mathrm{DW} 1 / 2$ are another ruthenium complexes with anticancer properties.

Hydantoin derivatives are well known for their medical applications, e.g. as antiepileptic drugs. ${ }^{18,19}$ Antiproliferative effects, ${ }^{20,21}$ inhibition of aldosoreductase ${ }^{22}$ and potential application for treatment of HIV-1 infections s $^{23,24}$ were also described. Recently, we reported the synthesis of various thioanalogues of cycloalkanespiro-5-hydantoins. ${ }^{25}$ The crystal structures of four cycloalkanespiro-5(2,4-dithiohydantoins), with different size of the saturated ring $^{26}$ and two cycloalkanespiro-5-(2-thiohydantoins $)^{27}$ were determined by means of single-crystal X-ray crystallography. Taking into account medical applications of hydantoin derivatives, it is of crucial importance to acquire the knowledge about their interactions with bioavailable metal ions. ${ }^{28}$

Although hydantoin compounds are studied extensively, there is not much research on their anticancer activities. In a previous work of ours, we have reported a method for obtaining 4'-bromo-(9'-fluorene)-spiro-5(2,4-dithiohydantoin). ${ }^{29}$ In the study cited above, we have investigated cytotoxic activities of the compound on the retinoblastoma cell line WERI-Rb-1 and antibacterial effects towards both, Gram-positive Staphylococcus aureus and Gram-negative Escherichia coli bacteria, as well as yeasts Candida albicans. The preliminary results of the cytotoxicity assay have shown that the compound could serve as a potential anticancer agent. Further investigations are needed to elucidate exact mechanisms of this action and to exclude any cytotoxic effect on normal cells. The results for the compound have shown no antimicrobial activity towards the bacteria Escherichia coli, Staphylococcus aureus and no activity towards Candida albicans. In another previous paper of ours, we have described a method for synthesis, examination of cytotoxicity and antibacterial effects of 3-amino-9'-fluorenespiro-5-hydantoin ${ }^{30}$ and new Pt(II) complexes of (9'-fluorene)-spiro-5-hydantoin and its 2-thio derivative. ${ }^{31}$ The two platinum complexes show significant effects on cancer cell growth compared to their ligands. Recently, we studied the complexation properties of cyclohexanespiro-5(2,4-dithiohydantoin) with copper and nickel. ${ }^{32}$ In a previous work of ours, we have presented the synthesis of $\mathrm{N}$ substituted tetralinspiro-5-hydantoins. ${ }^{33}$ Quantum-chemical calculations at DFT level are also performed to elucidate their structure.

Extensive publications and reviews, mainly from Raper, focus on the study of the donor behavior of heterocyclic thioamides and related ligands towards transition and non-transition metal ions, ${ }^{34-38}$ silver being the least referenced within the Group 11 metals. One of the points of interest arises from the $\mathrm{Cu}^{\mathrm{II}}$-thione redox chemistry as a way of modeling the electronic and structural properties of $\mathrm{Cu}$-cysteine environment in "blue" copper proteins. ${ }^{35}$ Recently, Beloglazkina et al. have obtained a Co(II) complex with 3-phenyl-5-(2-pyridylmethylene)2-thiohydantoin to use as a catalyst for the epoxidation of alkenes. ${ }^{39}$ Singh et al. have described complexes of thiohydantoin with $\mathrm{Co}(\mathrm{II}), \mathrm{Ni}(\mathrm{II})^{40}$ and $\mathrm{Sn}(\mathrm{IV}), \mathrm{Ti}(\mathrm{IV}){ }^{41}$ On the basis of IR data Singh shows that ligand actually coordinates as a monodentate through O-atom in Sn(IV) and $\mathrm{Ti}(\mathrm{IV})$ and through $\mathrm{S}$-atom in the $\mathrm{Co}(\mathrm{II})$ and $\mathrm{Ni}$ (II) complexes. Kandyl et al. have synthesized $\mathrm{Co}$ (II), Ni(II) and $\mathrm{Cu}(\mathrm{II})$ complexes of 5-(phenylazo)-2-thiohydantoin and 5-(2-hydroxyphenylazo)-2-thiohydantoin. ${ }^{42}$ Arrizabalaga et al. have synthesied Pt(II) and Pd(II) complexes with thiohydantoin. ${ }^{43}$ The complexes of $\mathrm{Pt}(\mathrm{II})$ and $\mathrm{Pd}(\mathrm{II})$ are involved thiohydantoin as bidentate ligand. The structure of $\mathrm{Tl}(\mathrm{I})$ complex of 5-benzylidene-2-thiohydantoin, ${ }^{44}$ and 5-(4'-dimethylaminobenzylidene)-2thiohydantoin ${ }^{45}$ are determined by X-ray methods. Recently, the molecular structure of cyclopentanespiro-5(2-thiohydantoin) and cyclohexanespiro-5-(2-thiohydantoin) have been established by X-ray analysis by Ahmedova et al. ${ }^{27}$ For cyclopentanespiro-5-(2-thiohydantoin) two crystallographicaly independent molecules are present in the asymmetric unit in contrast to its dithio-analogue. Cyclohexanespiro-5-(2-thiohydantoin) crystallized as a monohydrate similarly to the dioxo-analogue. ${ }^{46}$ The cyclopentane ring in cyclopentanespiro-5-(2-thiohydantoin) adopts envelope conformation, while the cyclohexane ring in cyclohexanespiro-5-(2-thiohydantoin) adopts chair conformation. Although the molecules of cyclopentanespiro-5-(2-thiohydantoin) and cyclohexanespiro-5-(2-thiohydantoin) possess the same proton donor and acceptor groups, the presence of the crystallization water in cyclohexanespiro-5-(2-thiohydantoin) leads to different hydrogen bonding types and patterns. In cyclopentanespiro-5-(2-thiohydantoin) $\mathrm{N}-\mathrm{H} \cdots \mathrm{O}$ and $\mathrm{N}-\mathrm{H} \cdots \mathrm{S}$ intermolecular hydrogen bonds are formed, while the intermolecular hydrogen bonds in cyclo-hexanespiro-5-(2-thiohydantoin) are of $\mathrm{O}-\mathrm{H} \cdots \mathrm{O}$, $\mathrm{O}-\mathrm{H} \cdots \mathrm{N}$ and $\mathrm{N}-\mathrm{H} \cdots \mathrm{S}$ types. The crystal structure of 2thiohydantoin was determined from X-ray data by Wal- 
ker et al. ${ }^{47}$ and the molecular structure of 5,5-diphenyl2 -thiohydantoin has been studied by Roszak et al. ${ }^{48}$ The structure of a substituted 2-thiohydantoin - S-[1-(3acetyl-5-oxo-2-thioxo-2,3,4,5-tetrahydro- $1 \mathrm{H}$-imidazol4-yl)ethyl] ethanethioate was established by Mackay. ${ }^{49}$ Only one crystal structure is available of the 1-acetyl-2thiohydantoin, ${ }^{50}$ with a substituent at first position in the hydantoin ring. Structure of Cs(I) complex of 5,5-dimethyl-2-thiohydantoin ${ }^{51}$ and $\mathrm{Tl}(\mathrm{I})$ complex of 5-(2pyridinyl-methylene)-2-thiohydantoin were also determined by X-ray data. ${ }^{52}$ The latter crystallized in triclinic crystals with $P 1$ space group. Solid state IR and solution phase ${ }^{1} \mathrm{H},{ }^{13} \mathrm{C}$ and ${ }^{205} \mathrm{Tl}$ NMR properties of the complex have also been investigated. However, there are no X-ray or other data for the metal complexes of cyclohexanespiro-5-(2-thiohydantoin) and cycloheptanespiro-5-(2thiohydantoin).

That is why, the research described here is focused on the synthesis of $\mathrm{Pt}(\mathrm{II})$ complexes of cyclohexanespiro5-(2-thiohydantoin) (L1) and cycloheptanespiro-5-(2thiohydantoin) (L2) and their characterization by elemental analysis, IR, ATR FTIR spectroscopy. The free ligands are described by UV-Vis, IR, and Raman spectroscopy. The QM calculations are performed with full geometrical optimization without any symmetry restrictions. The structures of the organic compounds used in this study are described in Scheme 1.

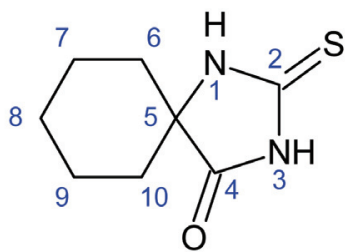

L1

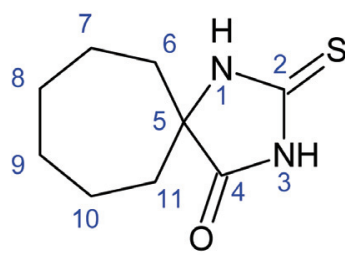

L2
Scheme 1. Structural formulae of cyclohexanespiro-5-(2-thiohydantoin) (L1) and cycloheptanespiro-5-(2-thiohydantoin) (L2)

It should be noted that the spirothiohydantoins, i.e. imidazolidine-2-thiones, present even more different ways of coordination (monodentate-A, bridging-B and chelating-C) due to the presence of two thioamide groups in a ligand (see Scheme 2).

\section{Experimental}

\section{1. Instrumentation and Methods}

A metal salt $\left(\left(\mathrm{NH}_{4}\right)_{2}\left[\mathrm{PtCl}_{4}\right]-\right.$ Sigma-Aldrich $)$ and solvents used for synthesis of the complexes were of p.a. quality. Electronic spectra were registered on a Lambda 9 Perkin-Elmer UV/Vis/NIR Spectrophotometer from 200 $\mathrm{nm}$ to $1000 \mathrm{~nm}$. The IR spectra of all compounds were re-

a)<smiles>[M]C1C(=O)NC(=S)N1C</smiles>

N1

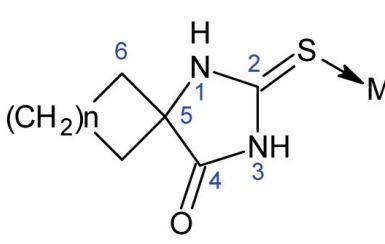

S2<smiles>[M]C1NC(=S)NC12C[Y10]2C</smiles><smiles>[M]OC1NC(=S)NC12C[Y10]2C</smiles>

N3
04

b)<smiles>[M]SC1NC(=O)C2(C[Y10]2C)N1[M]</smiles>

N1^S2<smiles>[M]SC1NC2(C[Y10]3CC32)C(=O)N1[M]</smiles>

N3^S2<smiles>[M]OC(=O)C12C[Y10](C)C1NC2=S</smiles>

N3^O4

c)

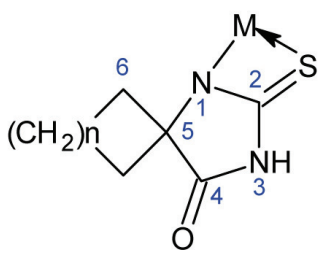

N1^S2

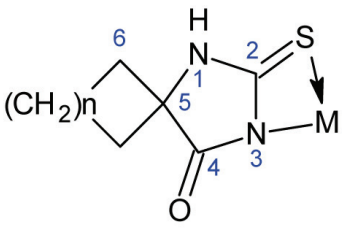

N3^S2

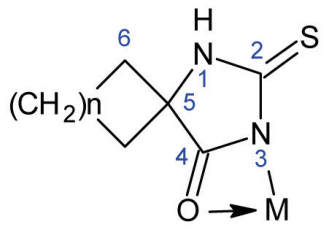

N3^O4

Scheme 2. Possible monodentate (a), bridging (b) and chelating (c) ways of coordination of cycloalkanespiro-5-(2-thiohydantoins) with metal ions (M). 
gistered in $\mathrm{KBr}$ pellets on a Bruker FT-IR VERTEX 70 spectrometer from $4000 \mathrm{~cm}^{-1}$ to $400 \mathrm{~cm}^{-1}$ at resolution 2 $\mathrm{cm}^{-1}$ with 25 scans. The Raman spectra of the free ligands were measured on a spectrometer RAM II (Bruker Optics) with a focused laser beam of $20 \mathrm{~mW}$ and $200 \mathrm{~mW}$ power of Nd:YAG laser (1064 nm) from $4000 \mathrm{~cm}^{-1}$ to $400 \mathrm{~cm}^{-1}$ at resolution $2 \mathrm{~cm}^{-1}$ with 25 scans). The NMR spectra were taken on a Bruker Avance II+ $600 \mathrm{MHz}$ NMR spectrometer operating at 600.130 and $150.903 \mathrm{MHz}$ for ${ }^{1} \mathrm{H}$ and ${ }^{13} \mathrm{C}$, respectively, using the standard Bruker software. Chemical shifts were referenced to tetramethylsilane (TMS). Measurements were carried out at ambient temperature.

\section{2. Synthesis of $\operatorname{Pt}($ II) Complexes of Cyclohexanespiro-5-(2-thiohydan- toin) (L1) and Cycloheptanespiro-5- (2-thiohydantoin) (L2)}

The solutions were prepared as follows:

$0.50 \mathrm{mmol}(0.092 \mathrm{~g})$ of cyclohexanespiro-5-(2thiohydantoin) (L1) or $0.50 \mathrm{mmol}(0.099 \mathrm{~g})$ of cycloheptanespiro-5-(2-thiohydantoin) (L2) in $15 \mathrm{~cm}^{3}$ DMSO and $10 \mathrm{~cm}^{3} \mathrm{H}_{2} \mathrm{O}$;

$0.50 \mathrm{mmol}(0.187 \mathrm{~g})$ of $\left(\mathrm{NH}_{4}\right)_{2}\left[\mathrm{PtCl}_{4}\right]$ in $25 \mathrm{~cm}^{3} \mathrm{H}_{2} \mathrm{O}$;

$0.1 \mathrm{M}$ aqueous solution of $\mathrm{NaOH}$ in a $100 \mathrm{~cm}^{3}$ volumetric flask.

5 drops or 3 drops of $0.1 \mathrm{M} \mathrm{NaOH}$ was added slowly to the solution of $\mathrm{L} 1$ or $\mathrm{L} 2$ while stirring at $\mathrm{pH}=8.3$ or 8.5. The solution of metal salt was added dropwise from a burette during stirring with electromagnetic stirrer. Neutral complexes were formed as yellow amorphous precipitates. The precipitates were filtered off and washed with $\sim 10-20 \mathrm{~cm}^{3} \mathrm{H}_{2} \mathrm{O}$. These were dried over $\mathrm{CaCl}_{2}$ for 2 weeks. It was found that the complexes were soluble in DMSO, $\mathrm{CH}_{3} \mathrm{OH}, \mathrm{C}_{2} \mathrm{H}_{5} \mathrm{OH}$ and insoluble in water. follows:

The spectral data of the compounds obtained are as

$\mathrm{UV}\left(\mathrm{C}_{2} \mathrm{H}_{5} \mathrm{OH}\right) \mathrm{L} 1: \lambda_{\max }=200,223,267 \mathrm{~nm}$.

IR (KBr) L1: v $3346(\mathrm{NH}), 3234(\mathrm{NH}), 3014,2948$ 2859 (aliph.), $1738\left(C^{4}=\mathrm{O}\right), 1619,1519\left(C^{2}=S\right), 1440$, 1376, 1294, 1167, $1062\left(C^{2}=S\right), 1035,992,963,939,930$, $911,854,836,788,763,706,621 \mathrm{~cm}^{-1}$.

Anal. Calc. for Pt(II)L: $\mathrm{C}_{16} \mathrm{H}_{22} \mathrm{~N}_{4} \mathrm{~S}_{2} \mathrm{O}_{2} \mathrm{Pt}: \mathrm{C} 34.19, \mathrm{H}$ 3.92, N 9.97. Found: C 33.92, H 4.06, N 9.49.

IR (KBr) Pt(II)L1: v $3446(\mathrm{NH}), 3003(\mathrm{NH})$, 2927-2854 (aliph.), $1708\left(\mathrm{C}^{4}=\mathrm{O}\right), 1520\left(\mathrm{C}^{2}=\mathrm{S}\right), 1454$, $1351,1280,1137,1059\left(C^{2}=S\right), 1024,975,949,912,854$, $836,778,732,691,626,518 \mathrm{~cm}^{-1}$.

Raman L1: v 2943, 2929, 2872, 2861, 2843, 2665, 1736, 1451, 1441, 1431, 1377, 1345, 1318, 1278, 1236, 1193, 1156, 1065, 1036, 992, 963, 931, 911, 836, 763, $621 \mathrm{~cm}^{-1}$.

${ }^{1} \mathrm{H}$ NMR $\left(600 \mathrm{MHz}, \mathrm{DMSO}-d_{6}\right) \mathrm{L} 1: \delta 1.27-1.65(\mathrm{~m}$, $10 \mathrm{H}), 10.48(\mathrm{~s}, 1 \mathrm{H}), 11.65(\mathrm{~s}, 1 \mathrm{H})$.
${ }^{1} \mathrm{H}$ NMR $\left(600 \mathrm{MHz}, \quad\right.$ DMSO- $\left.d_{6}\right)$ Pt(II)L1: $\delta$ $1.55-1.63(\mathrm{~m}, 10 \mathrm{H}), 10.49$ (s, 1H).

${ }^{13} \mathrm{C}$ NMR $\left(150 \mathrm{MHz}, \mathrm{DMSO}-d_{6}\right)$ L1: $\delta 181.32(\mathrm{C}-4)$, 179.20 (C-2), 65.67 (C-5), 32.99 (C-6, C-10), 24.78 (C8), 20.96 (C-7, C-9).

$\mathrm{UV}\left(\mathrm{C}_{2} \mathrm{H}_{5} \mathrm{OH}\right) \mathrm{L} 2: \lambda_{\max }=199,223,267 \mathrm{~nm}$.

IR (KBr) L2: $v 3447(\mathrm{NH}), 3163(\mathrm{NH}), 2932-2854$ (aliph), $1738\left(\mathrm{C}^{4}=\mathrm{O}\right), 1530\left(\mathrm{C}^{2}=\mathrm{S}\right), 1456,1392,1245$, 1191, 1091, $1035\left(\mathrm{C}^{2}=\mathrm{S}\right), 990,964,922,887,855,801$, 781, 722, 677, 647, 628, $594 \mathrm{~cm}^{-1}$.

Anal. Calc. for Pt(II)L2: $\mathrm{C}_{18} \mathrm{H}_{26} \mathrm{~N}_{4} \mathrm{~S}_{2} \mathrm{O}_{2} \mathrm{Pt}$ : C 36.63, H 4.41, N 9.50, Found: C 36.27, H 4.65, N 8.96.

IR (KBr) Pt(II)L2: v $3104(\mathrm{NH}), 3007(\mathrm{NH}), 2925-$ 2857 (aliph.), $1766\left(\mathrm{C}^{4}=\mathrm{O}\right), 1536\left(\mathrm{C}^{2}=\mathrm{S}\right), 1460,1407$, 1356, 1249, 1158, $1028\left(\mathrm{C}^{2}=\mathrm{S}\right), 985,952,888,852,803$, $742,626,597 \mathrm{~cm}^{-1}$.

Raman L2: v 3159, 2937, 2898, 2853, 2683, 1726, $1516,1445,1408,1361,1290,1249,1189,1149,1114$, 1092, 1048, 988, 954, 853, 779, 722, 651, $625 \mathrm{~cm}^{-1}$.

${ }^{1} \mathrm{H}$ NMR $\left(600 \mathrm{MHz}, \mathrm{DMSO}-d_{6}\right) \mathrm{L} 2: \delta 1.52-2.08$ $(\mathrm{m}, 12 \mathrm{H}), 10.37(\mathrm{~s}, 1 \mathrm{H}), 11.58(\mathrm{~s}, 1 \mathrm{H})$.

${ }^{1} \mathrm{H}$ NMR $\left(600 \mathrm{MHz}, \mathrm{DMSO}-d_{6}\right) \mathrm{Pt}(\mathrm{II}) \mathrm{L} 2: \delta 1.56-$ $2.00(\mathrm{~m}, 12 \mathrm{H}), 10.39(\mathrm{~s}, 1 \mathrm{H})$

${ }^{13} \mathrm{C}$ NMR (150 MHz, DMSO- $\left.d_{6}\right)$ L2: $\delta 180.98(\mathrm{C}-4)$, 180.42 (C-2), 68.15 (C-5), 40.37 (C-6, C-11), 29.61 (C-8, C-9), 22.32 (C-7, C-10).

\section{3. Theoretical Methods}

The ground-state equilibrium geometries of the ligands L1 and L2 and their complexes PtL1 (C1) and PtL2 (C2) were optimized at the BLYP/CEP-31G theoretical level. No symmetry and coordinate restrictions were applied (fully relaxed geometries during the optimization). The ligands L1 and L2 were optimized with spin multiplicity singlet while for the complexes $\mathrm{C} 1$ and $\mathrm{C} 2$ the multiplicity was set to quintet. The calculations were performed with the GAUSSIAN 03 program package. $^{53}$

\section{Results and Discussion}

Complexation with $\mathrm{Pt}(\mathrm{II})$ using a metal salt namely $\left(\mathrm{NH}_{4}\right)_{2}\left[\mathrm{PtCl}_{4}\right]$ at molar ratio $\mathrm{M}: \mathrm{L}=1: 1$ for $\mathrm{PtL}$ were conducted under alkaline conditions. Neutral complexes were synthesized and isolated as precipitates. The PtL1 (C1) and PtL2 (C2) complexes obtained have yellow colour. All complexes were investigated by IR spectroscopy and elemental analysis. Elemental analyses data was found to be in good agreement $(+0.5 \%)$ with the calculated values. It was found that the molar ratio metal:ligand is $1: 2$. Selected vibrational frequencies observed in the IR spectra of the complexes were compared with those of the free ligands in Table 1. 
In the IR spectrum of the free ligand L1 bands at $3346 \mathrm{~cm}^{-1}$ and $3234 \mathrm{~cm}^{-1}$ were observed and referred to the stretching vibrations of the two $\mathrm{N}-\mathrm{H}$ groups of the hydantoin ring (see Table 1). In the spectrum of the PtL1 complex the band resulting from the oscillation of the one of the two $\mathrm{N}-\mathrm{H}$ groups was observed at $3446 \mathrm{~cm}^{-1}$, which is about $100 \mathrm{~cm}^{-1}$ shifted to the larger frequencies as compared to the free ligand spectrum. The second band was missed. In the spectrum of free ligand L1, the bands at $1738 \mathrm{~cm}^{-1}$ and $1062 \mathrm{~cm}^{-1}$ could be assigned to vibrational oscillations of $\mathrm{C}^{4}=\mathrm{O}$ and $\mathrm{C}^{2}=\mathrm{S}$ groups of the hydantoin ring. The band resulting from the oscillation of the $\mathrm{C}^{4}=\mathrm{O}$ group in the IR spectrum of PtL1 complex is shifted to the lower frequencies by $30 \mathrm{~cm}^{-1}$ as compared to that of the free ligand. The vibrational oscillation of $\mathrm{C}^{2}=S$ group of the hydantoin ring was not change in the IR spectrum of PtL1 complex.

In the IR spectrum of the free ligand L2 bands at $3447 \mathrm{~cm}^{-1}$ and $3163 \mathrm{~cm}^{-1}$ were observed which we referred to the stretching vibrations of $\mathrm{N}-\mathrm{H}$ groups of the hydantoin ring. In the spectrum of the PtL2 complex the same band was observed at 3104 which is shifted to the lower frequencies by $59 \mathrm{~cm}^{-1}$ as compared to the free ligand spectrum. One of the two bands was missing in the spectrum of the PtL2 complex. In the spectrum of free ligand L2 the bands at $1738 \mathrm{~cm}^{-1}$ and $1035 \mathrm{~cm}^{-1}$ could be assigned to vibrational oscillations of $\mathrm{C}^{4}=\mathrm{O}$ and $\mathrm{C}^{2}=\mathrm{S}$ groups of the hydantoin ring. The band resulting from the oscillation of the $\mathrm{C}^{4}=\mathrm{O}$ group in the IR spectrum of PtL2 complex is shifted to the higher frequencies by $28 \mathrm{~cm}^{-1}$ as compared to that of the free ligand. In the spectrum of PtL2 complex the band at $1028 \mathrm{~cm}^{-1}$, which could be attributed to vibrational oscillation of $\mathrm{C}^{2}=\mathrm{S}$ group of the hydantoin ring was not change.

It was not possible to measure Raman spectra of the complexes - the sample bumed even at $1 \mathrm{~mW}$ laser power. Only the Raman spectra of the free ligands L1 and L2 were measured and discussed in the current paper (Table 2). The $C^{4}=\mathrm{O}$ stretching vibration of $\mathrm{L} 1$ appears at 1736 $\mathrm{cm}^{-1}$. The $\mathrm{C}^{2}=\mathrm{S}$ stretching vibration is appears at 1065 $\mathrm{cm}^{-1}$ in the Raman spectrum. Several bands in the Raman spectrum $\left(2943,2929,2872,2861\right.$ and $\left.2843 \mathrm{~cm}^{-1}\right)$ and in
Table 1. Selected IR bands $\left(\mathrm{cm}^{-1}\right)$ in $\mathrm{KBr}$ for the free ligand $\mathrm{L} 1$ and L2 and their Pt(II) complexes

\begin{tabular}{llll}
\hline $\mathbf{L 1}$ & $\mathbf{P t}(\mathbf{I I}) \mathbf{L 1}$ & $\mathbf{L 2}$ & $\mathbf{P t}(\mathbf{I I}) \mathbf{L 2}$ \\
\hline 3346 & 3446 & 3447 & - \\
3234 & - & 3163 & 3104 \\
3014 & 3003 & - & 3007 \\
$2948-2859$ & $2927-2854$ & $2932-2854$ & $2925-2857$ \\
1738 & 1708 & 1738 & 1766 \\
1519 & 1520 & 1530 & 1536 \\
1440 & 1454 & 1456 & 1460,1407 \\
1376 & 1351 & 1392 & 1356 \\
1294 & 1280 & 1245 & 1249 \\
1167 & 1137 & 1191 & 1158 \\
1062 & 1059 & 1035 & 1028 \\
\hline
\end{tabular}

the IR spectrum $\left(2948-2859 \mathrm{~cm}^{-1}\right)$ were assigned to the stretching vibrations of $\mathrm{CH}_{2}$ in the cyclohexane ring. The two vibrational bands of $v\left(\mathrm{~N}^{1}-\mathrm{H}\right)$ and $v\left(\mathrm{~N}^{3}-\mathrm{H}\right)$ in the Raman spectrum were not registered.

In the Raman spectrum of $\mathrm{L} 2$ the $\mathrm{C}^{4}=\mathrm{O}$ stretching vibration appears at $1726 \mathrm{~cm}^{-1}$. The $C^{2}=S$ stretching vibration appears as a weak band at $1048 \mathrm{~cm}^{-1}$ in the same spectrum. Several bands in the Raman spectrum (2937, 2898 and $2853 \mathrm{~cm}^{-1}$ ) and in the IR spectrum (2932-2854 $\mathrm{cm}^{-1}$ ) are for stretching vibrations of $\mathrm{CH}_{2}$ in the cycloheptane ring. One of the two vibrational bands in the Raman spectrum for $v\left(\mathrm{~N}^{1}-\mathrm{H}\right)$ and $v\left(\mathrm{~N}^{3}-\mathrm{H}\right)$ appears only lower frequency band (at $3159 \mathrm{~cm}^{-1}$ with a very low intensity).

IR technique is excellent for carbonyl species while the Raman analysis is quite variable. ${ }^{54}$ The carbonyl $\mathrm{C}=\mathrm{O}$ stretching vibration results in strong characteristic IR bands. Raman bands for thess vibrations are typically moderate to weak with some structures resulting in a strong $\mathrm{C}=\mathrm{O}$ stretch. The carbonyl $\mathrm{C}=\mathrm{O}$ stretching band was easily identified in the IR spectrum because of its intensity and its lack of interference with most of the other group frequencies.

The chemical structure of L1 and L2, as well as their $\mathrm{Pt}(\mathrm{II})$ complexes was established through ${ }^{1} \mathrm{H}$ and ${ }^{13} \mathrm{C}$ NMR spectroscopy. The ${ }^{1} \mathrm{H}$ NMR spectra of L1, L2 show

Table 2. Raman spectral data of free ligands L1 and L2

\begin{tabular}{ll}
\hline Compound & Raman spectral bands, $\mathbf{c m}^{\mathbf{- 1}}$ \\
\hline & $2943,2929,2872,2861,2843,2665,1736$, \\
& $1451,1441,1431,1377,1345,1318,1278$, \\
& $1236,1193,1156,1065,1036,992,963$, \\
& $931,911,836,763,621$ \\
& \\
cyclohexanespiro-5-(2-thiohydantoin) (L1) & $3159,2937,2898,2853,2683,1726,1516$, \\
& $1445,1408,1361,1290,1249,1189,1149$, \\
& $1114,1092,1048,988,954,853,779,722$, \\
& 651,625
\end{tabular}


resonance signals at $1.3-2.0 \mathrm{ppm}\left(\mathrm{CH}_{2}\right.$ protons of cycloalkane residue, multiplet) and two broad signals at $10.0-12.0 \mathrm{ppm}$ characteristic of $\mathrm{NH}$ protons. In the ${ }^{1} \mathrm{H}$ NMR spectra of PtL1 and PtL2 show resonance signals at 1.5-2.0 ppm $\left(\mathrm{CH}_{2}\right.$ protons of cycloalkane residue, multiplet) and one broad signal at 10.49 and $10.39 \mathrm{ppm}$ characteristic of $\mathrm{NH}$ proton, respectively. This fact shows that the one of the two $\mathrm{NH}$ groups participates in the coordination with the metal ion. The ${ }^{13} \mathrm{C}$ NMR spectra of $\mathrm{L} 1$ and L2 show resonance peaks of C-2, C-4 and C-5 of the thioanalogues of spirohydantoins at 179 and $180 \mathrm{ppm}, 181$ ppm and 65.7 and $68.2 \mathrm{ppm}$, respectively.

Optimized geometries in Fig. 1 show that the ligand L1 has a chair conformation of the cyclohexane ring and a planar structure of the aromatic residue. We have identified a chair conformation of the cycloheptane ring either.

Regarding the complexes $\mathrm{C} 1$ and $\mathrm{C} 2$, one can see that the chair conformations of the cyclohexane / cycloheptane rings are kept. Two valent bonds are formed between $\mathrm{Pt}(\mathrm{II})$ and the nitrogen, and oxygen atoms from the planar rings. Weak bonds (over $3 \AA$ ) are formed between the remaining nitrogen and the oxygen atoms of the rings. These bonds are a bit longer in the complex $\mathrm{C} 2$ than in the

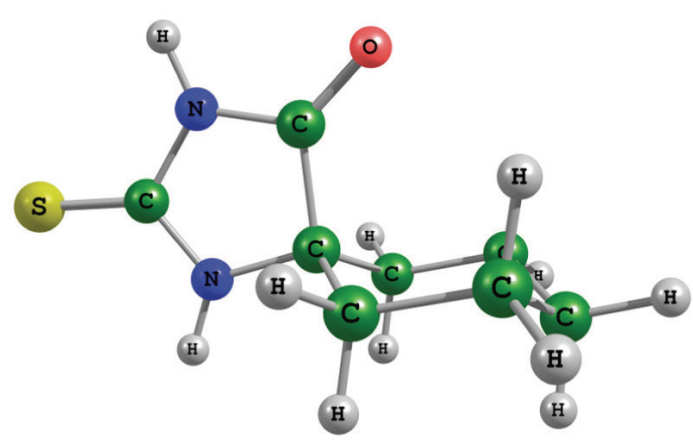

L1

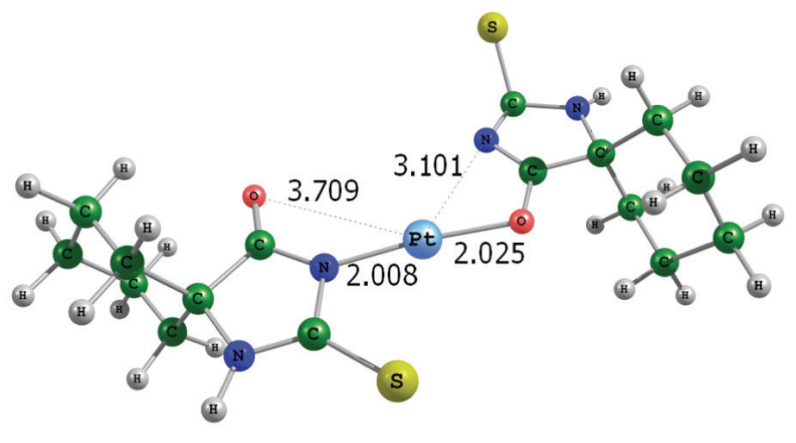

C1 complex $\mathrm{C} 1$, probably due to the influence of the large hydrocarbon ring (steric hindrance).

In the two complexes one of the sulfur atoms (the ring which forms coordination valent bond between the carbonyl oxygen atom and $\mathrm{Pt}(\mathrm{II})$ ) is considerably deviated from the aromatic ring: $\angle \mathrm{SCNN}=129^{\circ}$ (in $\mathrm{C} 1$ ) and $<\mathrm{SC}$ $\mathrm{NN}=130^{\circ}$ (in C2). We explain this fact with the strong repulsion between the sulfur atom and the weakly bonded carbonyl oxygen atom of the other ring to $\mathrm{Pt}(\mathrm{II})$. The complexes $\mathrm{C} 1$ and $\mathrm{C} 2$ are planar with respect to the bonded atoms to $\mathrm{Pt}(\mathrm{II})$.

For two Pt(II) complexes square planar geometry are suggested with two ligand molecules coordinated in a bidentate fashion similar to four membered chelat in $\mathrm{Ni}$ (II) complex of (9'-fluorene)-spiro-5-dithiohydantoin, ${ }^{55} \mathrm{Tl}(\mathrm{I})$ complex with 5-(2-pyridinylmethylene)-2- thiohydantoin, ${ }^{52}$ 5-(4'-dimethylaminobenzylidene)-2-thiohydantoin ${ }^{45}$ and $\mathrm{Pt}(\mathrm{II})$ and $\mathrm{Pd}(\mathrm{II})$ complexes with thiohydantoin. ${ }^{43}$

\section{Conclusions}

Two new metal complexes of cyclohexanespiro-5(2-thiohydantoin) (L1) and cycloheptanespiro-5-(2-

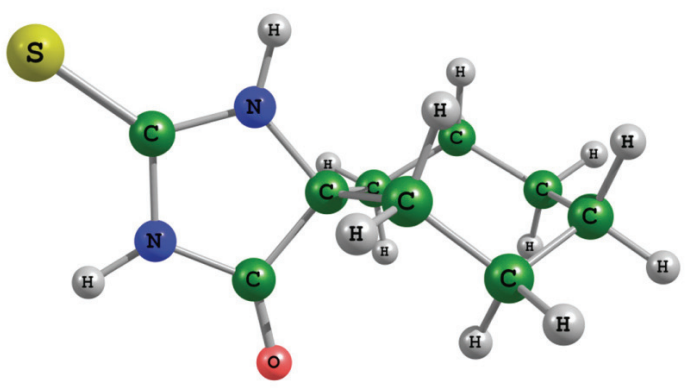

L2

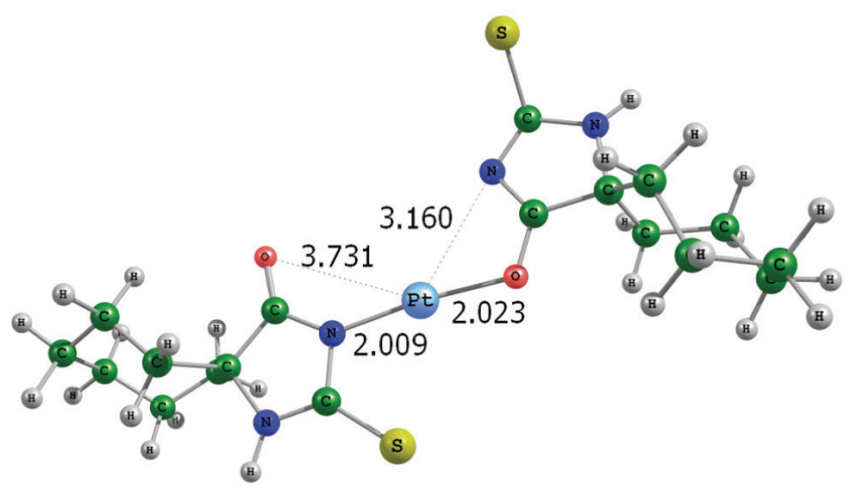

C2

Figure 1. Ground-state equilibrium geometries of the ligand and complexes of cyclohexanespiro-5-(2-thiohydantoin) (L1) and cycloheptanespiro5-(2-thiohydantoin) (L2) as obtained at the BLYP/CEP-31G level 
thiohydantoin) (L2) were obtained with $\mathrm{Pt}(\mathrm{II})$. They were characterized by elemental analysis, vibrational IR and ${ }^{1} \mathrm{H}$ NMR spectroscopy. Cyclohexanespiro-5-(2-thiohydantoin) and cycloheptanespiro-5-(2-thiohydantoin) were studied by UV-Vis, IR, ${ }^{1} \mathrm{H},{ }^{13} \mathrm{C}$ NMR and Raman spectroscopy. Based on the experimental data, the most probable structure for the PtL1 and PtL2 complexes was suggested with two deprotonated $\mathrm{NH}$ groups of ligand L1 or L2. For two Pt(II) complexes square planar geometry was suggested with two ligand molecules coordinated in a bidentate fashion $(\mathrm{N} 3 \wedge \mathrm{O} 4)$.

\section{Acknowledgements}

This work has been supported by the Scientific research Department (NPD) at University of Plovdiv, contract NI-13-HF-006, and contract DFNI BO1/0014 supported by the National Science Fund of Bulgaria. We are also grateful to Assoc. Prof. Dr. Plamen Penchev for the spectra measurements.

\section{References}

1. L. Kelland, Nat. Rev. Cancer. 2007, 7, 573-584. http://dx.doi.org/10.1038/nrc2167

2. G. Daugaard, U. Abildgaard, Cancer Chemother. Pharmacol. 1989, 25, 1-9. http://dx.doi.org/10.1007/BF00694330

3. E. Cvitkovic, Cancer Treat. Rev. 1998, 24, 265-281. http://dx.doi.org/10.1016/S0305-7372(98)90061-5

4. D. Screnci, M. J. McKeage, J. Inorg. Biochem. 1999, 77, 105-110. http://dx.doi.org/10.1016/S0162-0134(99)00135-X

5. L. Galluzzi, L. Senovilla, I. Vitale, J. Michels, I. Martins, O. Kepp, M. Castedo, G. Kroemer, Oncogene 2012, 31, 18691883. http://dx.doi.org/10.1038/onc.2011.384

6. D.-W. Shen, L. M. Pouliot, M. D. Hall, M. M. Gottesman, Pharmacol. Rev. 2012, 64, 706-721. http://dx.doi.org/10.1124/pr.111.005637

7. E. Wong, C. M. Giandomenico, Chem. Rev. 1999, 99, 24512466. http://dx.doi.org/10.1021/cr980420v

8. N. J. Wheate, S. Walker, G. E. Craig, R. Oun, Dalton Trans. 2010, 39, 8113-8127. http://dx.doi.org/10.1039/c0dt00292e

9. J. J. Wilson, S. J. Lippard, Chem. Rev. 2014, 114, 44704495.

http://dx.doi.org/10.1021/cr4004314

10. A. G. Quiroga, Curr. Top. Med. Chem. 2011, 11, 2613-2622. http://dx.doi.org/10.2174/156802611798040723

11. L. Kelland, Nature Rev. Cancer 2007, 7, 573-584. http://dx.doi.org/10.1038/nrc2167

12. N. Stojanović, D. Urankar, A. Brozović, A. Ambriović-Ri- stov, M. Osmak, J. Košmrlj, Acta Chim. Slov. 2013, 60, 368374.

13. M. Saeidifar, H. Mansouri-Torshizi, Y. Palizdar, M. EslamiMoghaddam, A. Divsalar, A. A. Saboury, Acta Chim. Slov. 2014, 61, 126-136.

14. A. Bergamo, C. Gaiddon, J.H.M. Schellens, J.H. Beijnen, G. Sava, J. Inorg. Biochem. 2012, 106, 90-99. http://dx.doi.org/10.1016/j.jinorgbio.2011.09.030

15. E. S. Antonarakis, A. Emadi, Cancer Chemoth. Pharm. 2010, 66, 1-9. http://dx.doi.org/10.1007/s00280-010-1293-1

16. M. Galanski, V. Arion, M. Jakupec, B. Keppler, Curr. Pharm. Des. 2003, 9, 2078-2089.

http://dx.doi.org/10.2174/1381612033454180

17. H. Chen, J. A. Parkinson, S. Parsons, R. A. Coxall, R. O. Gould, P. J. Sadler, J. Am. Chem. Soc. 2002, 124, 30643082 . http://dx.doi.org/10.1021/ja017482e

18. D. Janz, Der Nervenarzt 1950, 21, 113-119.

19. T. C. Butler, W. J. Waddell, J. Pharm. Exp. Therapeut. 1954, 110, 120-125.

20. C. S. A. Kumar, S. B. B. Prasad, K. Vinaya, S. Chandrappa, N. R. Thimmegowda, S. R. Ranganatha, S. Swarup, K. S. Rangappa, Inv. New Drugs 2009, 27, 131-139. http://dx.doi.org/10.1007/s10637-008-9150-3

21. C. V. Kavitha, M. Nambiar, C. S. Ananda Kumar, B. Choudhary, K. Muniyappa, K. S. Rangappa, S. C. Raghavan, Biochem. Pharmacol. 2009, 77, 348-363.

http://dx.doi.org/10.1016/j.bcp.2008.10.018

22. R. Sarges, R. C. Schnur, J. L. Belletire, M. J. Peterson, J. Med. Chem. 1988, 31, 230-243. http://dx.doi.org/10.1021/jm00396a037

23. D. Kim, L.P. Wang, C. G. Caldwell, P. Chen, P. E. Finke, B. Oates, M. MacCoss, S. G. Mills, L. Malkowitz, S. L. Gould, J. A. DeMartino, M. S. Springer, D. Hazuda, M. Miller, J. Kessler, R. Danzeisen, G. Carver, A. Carella, K. Holmes, J. Lineberger, W. A. Schleif, E. A. Emini, Bioorg. Med. Chem. Lett. 2001, 11, 3099-3102. http://dx.doi.org/10.1016/S0960-894X(01)00654-0

24. D. Kim, L. Wang, C. G. Caldwell, P. Chen, P. E. Finke, B. Oates, M. MacCoss, S. G. Mills, L. Malkowitz, S. L. Gould, J. A. DeMartino, M. S. Springer, D. Hazuda, M. Miller, J. Kessler, R. Danzeisen, G. Carver, A. Carella, K. Holmes, J. Lineberger, W. A. Schleif, E. A. Eminic, Bioorg. Med. Chem. Lett. 2001, 11, 3103-3106. http://dx.doi.org/10.1016/S0960-894X(01)00655-2

25. M. Marinov, S. Minchev, N. Stoyanov, G. Ivanova, M. Spassova, V. Enchev, Croat. Chem. Acta 2005, 78, 9-16.

26. B. Shivachev, R. Petrova, P. Marinova, N. Stoyanov, A. Ahmedova, M. Mitewa, Acta Crystallogr. C 2006, 62, o211o215. http://dx.doi.org/10.1107/S0108270106003489

27. A. Ahmedova, G. Pavlović, M. Marinov, N. Stoyanov, D. Šišak, M. Mitewa, J. Mol. Str. 2009, 938, 165-173. http://dx.doi.org/10.1016/j.molstruc.2009.09.021

28. V. Enchev, N. Stoyanov, V. Mateva, J. Popova, M. Kashchie- 
va, B. Aleksiev, M. Mitewa, Struct. Chem. 1999, 10, 381385 . http://dx.doi.org/10.1023/A:1022047628765

29. P. Marinova, M. Marinov, Y. Feodorova, M. Kazakova, D. Georgiev, E. Trendafilova, P. Penchev, V. Sarafian, N. Stoyanov, University of Ruse "A. Kanchev" Proceedings, Chemical technologies 2013, 52, 33-37.

30. P. Marinova, M. Marinov, M. Kazakova, Y. Feodorova, D. Georgiev, V. Lekova, P. Penchev, N. Stoyanov, Compt. Rend. Acad. Bulg. Sci. 2014, 67, 513-518.

31. P. Marinova, M. Marinov, M. Kazakova, Y. Feodorova, P. Penchev, V. Sarafian, N. Stoyanov, Biotechnol. Biotec. Eq. 2014, 28, 316-321. http://dx.doi.org/10.1080/13102818.2014.910363

32. A. Ahmedova, P. Marinova, K. Paradowska, N. Stoyanov, I. Wawer, M. Mitewa, Inorg. Chim. Acta, 2010, 363, 39193925. http://dx.doi.org/10.1016/j.ica.2010.07.050

33. M. Marinov, P. Marinova, N. Stoyanov, N. Markova, V. Enchev, Acta Chim. Slov. 2014, 61, 420-424.

34. E. S. Raper, Coord. Chem. Rev. 1994, 129, 91-156. http://dx.doi.org/10.1016/0010-8545(94)85019-4

35. E. S. Raper, Coord. Chem. Rev. 1996, 153, 199-255. http://dx.doi.org/10.1016/0010-8545(95)01233-8

36. E. S. Raper, Coord. Chem. Rev. 1997, 165, 475-567. http://dx.doi.org/10.1016/S0010-8545(97)90167-3

37. J. A. Garcia-Vazquez, J. Romero, A. Sousa, Coord. Chem. Rev. 1999, 193-195, 691-745. http://dx.doi.org/10.1016/S0010-8545(99)00046-6

38. P. D. Arkivos, Coord. Chem. Rev. 2001, 213, 181-210. http://dx.doi.org/10.1016/S0010-8545(00)00372-6

39. E. K. Beloglazkina, A. G. Majouga, R. B. Romashkina, N. V. Zyk, Tetrahedron Lett. 2006, 47, 2957-2959. http://dx.doi.org/10.1016/j.tetlet.2006.02.098

40. P. Singh, U. Shukla, A. Srivastava, Aust. J. Chem. 1976, 29 , 79-84. http://dx.doi.org/10.1071/CH9760079

41. P. Singh, U. Shukla, Aust. J. Chem. 1974, 27, 1827-1832. http://dx.doi.org/10.1071/CH9741827

42. S. S. Kandil, G. B. El-Hefnawy, E. A. Baker, Thermochim. Acta 2004, 414, 105-113. http://dx.doi.org/10.1016/j.tca.2003.11.021

43. P. Arrizabalaga, P. Castan, J.-P. Laurent, Transition Met. Chem. 1980, 5, 324-327.

http://dx.doi.org/10.1007/BF01396951

44. J. S. Casas, E. E. Castellano, M. D. Couce, N. Playa, A. Sanchez, J. Sordo, J. M. Varela, J. Zukerman-Schpector, J. Coord. Chem. 1999, 47, 299-313. http://dx.doi.org/10.1080/00958979908023062

45. J. S. Casas, À. Castineiras, N. Playa, A. Sanchez, J. Sordo, J. M. Varela, E. M. Vazquez-Lopez, Polyhedron 1999, 18, 3653-3659.

46. T. J. Gauthier, T. S. Yokum, G. A. Morales, M. L. McLaughlin, Y.-H., Liu, F. R. Fronczek, Acta Crystallogr., Sect. C 1997, 53, 1659-1661.

http://dx.doi.org/10.1107/S0108270197007488

47. L. A. Walker, K. Folting, L. L. Merritt Junior, Acta Crystallogr., Sect. B: Struct. Sci. 1969, 25, 88-93. http://dx.doi.org/10.1107/S0567740869001804

48. A. W. Roszak, D. F. Weaver, Acta Crystallogr. Sect. C 1998, $54,1168-1170$. http://dx.doi.org/10.1107/S0108270197019963

49. M. F. Mackay, B. M. Duggan, R. L. Laslett, J. F. K. Wilshire, Acta Crystallogr., Sect. C 1992, 48, 334-336. http://dx.doi.org/10.1107/S0108270191009575

50. J. S. Casas, A. Castineiras, D. Couce, N. Playa, J. Sordo, J. M. Varela, Acta Crystallogr., Sect. C 1998, 54, 427-428. http://dx.doi.org/10.1107/S0108270197014960

51. M. Arca, F. Demartin, F. A. Devillanova, A. Garau, F. Isaia, V. Lippolis, G. Verani, Inorg. Chem. 1998, 37, 4164-4165.

52. J. S. Casas, E. E. Castellano, A. Macias, N. Playa, A. Sanchez, J. Sordo, J. Varela, J. Zukerman-Shpector, Inorg. Chim. Acta 1995, 238, 129-137. http://dx.doi.org/10.1016/0020-1693(95)04693-4

53. M. T. Frisch et al., 2004, GAUSSIAN 03, Revision D.01. Gaussian, Wallingford.

54. P. J. Larkin, Infrared and Raman Spectroscopy. Principles and Spectral Interpretation, Elsevier, 2011, pp.126.

55. A. Ahmedova, P. Marinova, K. Paradowska, M. Marinov, M. Mitewa, J. Mol. Struct. 2008, 892, 13-19. http://dx.doi.org/10.1016/j.molstruc.2008.04.053

\section{Povzetek}

Predstavljena je sinteza in karakterizacija dveh novih Pt(II) kompleksov s cikloheksanspiro-5-(2-tiohidantoinom) (L1) in cikloheptanspiro-5-(2-tiohidantoinom) (L2). Kompleksa sta bila študirana z elementno analizo, IR in ${ }^{1} \mathrm{H}$ NMR spektroskopijo. Liganda sta bila analizirana z UV-Vis, IR, ${ }^{1} \mathrm{H}$ NMR, ${ }^{13} \mathrm{C}$ NMR in Ramansko spektroskopijo. Geometrijska optimizacija ligandov L1 in L2 ter njunih kompleksov s Pt(II) je bila izvedena na BLYP/CEP-31G nivoju. 